Article

\title{
Effects of Straw Incorporation on Soil Nutrients, Enzymes, and Aggregate Stability in Tobacco Fields of China
}

\author{
Jiguang Zhang ${ }^{1}$, Guodong Bo ${ }^{1}$, Zhongfeng Zhang ${ }^{1}$, Fanyu Kong ${ }^{1}$, Yi Wang ${ }^{2}$ \\ and Guoming Shen ${ }^{1, *}$ \\ 1 Key Laboratory of Tobacco Biology and Processing, Ministry of Agriculture, \\ Tobacco Research Institute of Chinese Academy of Agriculture Sciences, Qingdao 266101, China; \\ zhangjiguang@caas.cn (J.Z.); boguodong123@163.com (G.B.); zhangzhongfeng@caas.cn (Z.Z.); \\ kongfanyu@caas.cn (F.K.) \\ 2 Weifang Tobacco Co., Ltd. of Shandong Province, Weifang 262200, China; bomb_wangyi@163.com \\ * Correspondence: shenguoming@caas.cn; Tel.: +86-532-6671-5079; Fax: +86-532-8870-3386 \\ Academic Editor: Vincenzo Torretta \\ Received: 29 April 2016; Accepted: 18 July 2016; Published: 26 July 2016
}

\begin{abstract}
To determine the effects of straw incorporation on soil nutrients, enzyme activity, and aggregates in tobacco fields, we conducted experiments with different amounts of wheat and maize straw in Zhucheng area of southeast Shandong province for three years (2010-2012). In the final year of experiment (2012), straw incorporation increased soil organic carbon (SOC) and related parameters, and improved soil enzyme activity proportionally with the amount of straw added, except for catalase when maize straw was used. And maize straw incorporation was more effective than wheat straw in the tobacco field. The percentage of aggregates $>2 \mathrm{~mm}$ increased with straw incorporation when measured by either dry or wet sieving. The mean weight diameter (MWD) and geometric mean diameter (GMD) in straw incorporation treatments were higher than those in the no-straw control (CK). Maize straw increased soil aggregate stability more than wheat straw with the same incorporation amount. Alkaline phosphatase was significantly and negatively correlated with soil $\mathrm{pH}$. Sucrase and urease were both significantly and positively correlated with soil alkali-hydrolysable $\mathrm{N}$. Catalase was significantly but negatively correlated with soil extractable K (EK). The MWD and GMD by dry sieving had significantly positive correlations with SOC, total N, total K, and EK, but only significantly correlated with EK by wet sieving. Therefore, soil nutrients, metabolic enzyme activity, and aggregate stability might be increased by increasing the SOC content through the maize or wheat straw incorporation. Moreover, incorporation of maize straw at $7500 \mathrm{~kg} \cdot \mathrm{hm}^{-2}$ was the best choice to enhance soil fertility in the tobacco area of Eastern China.
\end{abstract}

Keywords: soil organic carbon; enzyme activity; mean weight diameter; geometric mean diameter; tobacco field

\section{Introduction}

In China, farmers traditionally incorporated straw into soil to improve soil fertility, but in recent years, most straws have been burned to save labor, which was a waste of nutrient resources, affected road safety due to reduced visibility, and caused air pollution [1]. Straw incorporation is an important management practice with the potential to reduce dependence on mineral fertilizers and to maintain soil nutrient balance and soil structure [2]. As with other organic amendments, straw incorporation provides nutrients for plant growth and the organic carbon serves as an energy supply for soil microorganisms. Many researches show that straw incorporation can increase soil organic carbon [3], regulate $\mathrm{CO}_{2}$ and $\mathrm{CH}_{4}$ emissions [4], change soil aggregate size distribution [1,5], and increase crop 
production [6,7]. Therefore, straw incorporation may be an important method to improve soil fertility and sustainable agricultural development [8].

Soil enzymes can catalyze innumerable reactions necessary for life processes of soil microorganisms, decomposition of organic residues, cycling of nutrients, and formation of organic matter and soil structure [9]. They are synthesized, accumulated, inactivated, or decomposed in soil; and play important roles in soil nutrient cycling and seem to be an important indicator of soil quality $[10,11]$. Soil enzymes may activate potential soil nutrients, and vice versa. Changes in soil physical and chemical characters directly influence soil enzyme activity. Soil enzyme activities are increased to different degrees by the incorporation of organic manure and have a significant positive relationship with organic $\mathrm{C}$ and total $\mathrm{N}$ [12]. In addition, straw incorporation has significant roles in improving the activity levels of soil enzymes and soil microbial biomass [13,14]. Thus, straw incorporation could be an important way to improve soil fertility from the point view of soil enzyme.

Soil aggregates are the basic units of soil structure and they comprise primary particles and binding agents. The soil aggregates and the pores between them affect water movement and storage, aeration, erosion, biological activity, and the growth of crops [15]. Thus, soil aggregates influence a wide range of physical and biogeochemical processes in the agricultural environment [16]. They are also necessary for high soil quality and productivity. Soil aggregate stability is a crucial soil property affecting soil sustainability, productivity, and crop production. However, soil aggregate formation and stabilization are affected by several factors; the straw residue quality and amount play very important roles in the process of aggregate formation [17]. A certain amount of easily-decomposed straw residue could cause a rapid stimulation of the soil microflora and soil enzyme activities by providing the soil organic matter [18,19]. Meanwhile, this is accompanied by the formation of stable aggregates and an increase in aggregate stability [20,21]. Crop residue incorporation can improve soil structural stability, as large amounts of residue with a moderate $\mathrm{C} / \mathrm{N}$ ratio stabilize aggregates for longer periods [22]. Zhang et al. [2] found that straw incorporation increased soil macro-aggregate size distribution and soil aggregate stability in the $0-40 \mathrm{~cm}$ deep soil in semi-arid areas of Northwest China. Maintaining high soil aggregate stability by incorporating straw is required. Many researchers have proved that straw incorporation into the soil is an effective strategy to increase soil organic matter contents in agricultural ecosystem. Then it has great meaning to maintain the sustainable use of soil by improving soil enzyme activity, soil aggregation, and stability $[12,23,24]$.

In tobacco fields of China, too much attention has been given to the application of chemical fertilizers. It is difficult to maintain soil fertility when there is no, or low, input of organic materials into the soil. All tobacco straws are removed from the field after the harvest for soil-borne disease control, which would lead to the degradation of tobacco leaf quality by affecting the soil nutrient balance. Therefore, the straw incorporation of other crops into tobacco-field soil may be a method to improve soil physical and chemical properties while maintaining tobacco quality and soil ecosystem health. However, the effects of incorporating different straws on soil nutrients, enzymes, and soil aggregates in tobacco fields are seldom studied, and then to choose the suitable amount of straw incorporation. The objective of this study is: (1) to investigate the effects of wheat and maize straw incorporation on soil nutrients, enzyme activities, composition and stability of soil aggregates in the study area; (2) to evaluate the relationships between soil enzymes, aggregate stability, and soil nutrients in the straw incorporated field; (3) and to determine the suitable straw type and incorporation amount in this important tobacco planting area of China.

\section{Materials and Methods}

\subsection{Site Description and Soil Sampling}

The experiment was conducted from 2010 and lasted for three years in a cropland area of Da Shun-he village $\left(119^{\circ} 31^{\prime} \mathrm{E}, 36^{\circ} 08^{\prime} \mathrm{N}\right.$, approximately $220 \mathrm{~m}$ above sea level), Zhucheng County, in southeast Shandong province, China. The research area is representative of a typical temperate 
monsoon climate with an average annual rainfall of $799.7 \mathrm{~mm}$, more than $60 \%$ of which falls during the flood period (June to August). Floods pose a serious threat to local agriculture. The mean annual temperature is approximately $12.0^{\circ} \mathrm{C}$ and there are, on average, $2578.4 \mathrm{~h}$ of sunshine per year. The cropland is cultivated with flue-cured tobacco for more than five years. The soil is developed from limestone and classified as a Stagnic Anthrosol [25] with $18.0 \%$ clay $(<0.002 \mathrm{~mm}), 25.5 \%$ silt $(0.02-0.002 \mathrm{~mm})$, and $56.5 \%$ sand $(2-0.02 \mathrm{~mm})$. Other main characteristics of the soil before the experiment beginning at 0-20 cm depth are as follows: $\mathrm{pH} 6.10$, soil organic carbon $9.13 \mathrm{~g} \cdot \mathrm{kg}^{-1}$, total $\mathrm{N} 0.72 \mathrm{~g} \cdot \mathrm{kg}^{-1}$, total $\mathrm{P}, 0.76 \mathrm{~g} \cdot \mathrm{kg}^{-1}$, total K $19.02 \mathrm{~g} \cdot \mathrm{kg}^{-1}$, alkali-hydrolysable $\mathrm{N} 62.54 \mathrm{mg} \cdot \mathrm{kg}^{-1}$, available phosphorus $\left(\mathrm{P}_{\text {Olsen }}\right) 28.70 \mathrm{mg} \cdot \mathrm{kg}^{-1}$, and extractable $\mathrm{K} 160.87 \mathrm{mg} \cdot \mathrm{kg}^{-1}$.

The experiment was carried out with a complete randomized design with three replicates. The experiment included seven treatments: no straw incorporation (CK); incorporation of maize straw (M1) or wheat straw (W1) at a low rate of $1500 \mathrm{~kg} \cdot \mathrm{hm}^{-2}$; incorporation of maize straw (M2) or wheat straw (W2) at a middle rate of $4500 \mathrm{~kg} \cdot \mathrm{hm}^{-2}$; and incorporation of maize straw (M3) or wheat straw (W3) at a high rate of $7500 \mathrm{~kg} \cdot \mathrm{hm}^{-2}$. Each plot was $72 \mathrm{~m}^{2}$ and separated by ridges to avoid cross contamination among plots. Maize and wheat straws were both crushed into $1-2 \mathrm{~cm}$ pieces and plowed into soil during the tillage, 30 days before the tobacco transplantation every year. The total carbon $(\mathrm{C})$, nitrogen $(\mathrm{N})$, phosphorus $\left(\mathrm{P}_{2} \mathrm{O}_{5}\right)$, and potassium $\left(\mathrm{K}_{2} \mathrm{O}\right)$ content in the maize straw were $405.56,8.72,1.17$, and $12.80 \mathrm{~g} \cdot \mathrm{kg}^{-1}$, respectively; the same nutrients were $323.21,6.15,1.73$, and $9.72 \mathrm{~g} \cdot \mathrm{kg}^{-1}$, respectively, in wheat straw. The mineral (calcium superphosphate, potassium sulfate, and compound fertilizers) and organic fertilizer (soya cake) were applied each year at the tobacco planting field. All fertilizer rates in each treatment were 120-120-360 kg N-P $\mathrm{P}_{2} \mathrm{O}_{5}-\mathrm{K}_{2} \mathrm{O}$ per hm${ }^{2}$ with the ratio around 1:1:3. In addition, $75 \%$ of the amount of chemical fertilizer and all the organic fertilizer were applied as basal application; the remaining $25 \%$ of chemical fertilizer was applied as topdressing in the experiment.

\subsection{Soil Sampling}

Composite soil samples (five random core samples from each plot, thoroughly mixed together) were collected from the surface layer $(0-20 \mathrm{~cm})$ in each plot (i.e., replicate) when the tobacco matured in the October of the year 2012. Visible roots and fragments of organic debris were removed manually before the samples were ground to pass through a $2 \mathrm{~mm}$ sieve and dried naturally for soil nutrient and enzyme activity analyses. Meanwhile, undisturbed fresh soil samples were collected from the treatment plots at the same time for soil aggregate analysis.

\subsection{Soil Nutrients Analysis}

Soil $\mathrm{pH}$ (in distilled water, 1:2.5 $w / v$ ) was measured using a $\mathrm{pH}$ meter equipped with a glass electrode. Soil organic carbon (SOC), total N (TN), total P (TP), and total K (TK) were determined with air-dried soil passed through a $0.153 \mathrm{~mm}$ sieve using standard methods [26]. Alkali-hydrolysable $\mathrm{N}$ (AH-N, NaOH), $\mathrm{P}_{\mathrm{Olsen}}$, and ammonium acetate extractable $\mathrm{K}(\mathrm{EK})$ were determined with air-dried soil passed through a $2 \mathrm{~mm}$-sieve [27].

\subsection{Soil Enzyme Analysis}

Activities of sucrase, urease, and alkaline phosphatase in soil were measured using colorimetry. And the catalase activity was determined by volumetric titration. Sucrase activity was determined by 3,5-dinitrosalicylic acid colorimetry using sucrose as the substrate. It was expressed as mg glucose $\mathrm{g}^{-1}$ dry soil $24 \mathrm{~h}^{-1}$ [23]. Soil urease activity was measured using indophenol colorimetry with urea as the substrate. Briefly, ammonium was released over $1 \mathrm{~h}$ and assayed colorimetrically at $578 \mathrm{~nm}$. Soil urease activity was expressed as $\mathrm{mg} \mathrm{NH}_{4}{ }^{+}-\mathrm{N} \mathrm{kg}^{-1}$. dry $\cdot$ soil. $\mathrm{h}^{-1}$ [28]. Soil alkaline phosphatase activity was determined with disodium phenyl phosphate colorimetry according to the methods of Ge et al. [29], and catalase activity was determined according to the methods of $\mathrm{Xu}$ and Zheng [30]. The alkaline phosphatase activity was expressed as $\mathrm{mg}$ p-nitrophenol released $\mathrm{g}^{-1} \cdot \mathrm{dry} \cdot \mathrm{soil} \cdot \mathrm{h}^{-1}$, and catalase 
activity was expressed as $\mathrm{ml} 0.1 \mathrm{~N} \mathrm{KMnO}_{4} \mathrm{~g}^{-1}$. dry soil. $20 \mathrm{~min}^{-1}$. All determinations of enzymatic activities were performed in triplicate and values reported as means.

\subsection{Soil Aggregate Analysis}

Soil aggregate analysis followed the methods already described [31,32]. Fresh soil samples were passed through an $8 \mathrm{~mm}$ sieve by gently breaking the soil clods along natural planes of fracture after the removal of visible plant residues and stones. After the sample was air-dried, it was separated into three subsamples to measure soil aggregate size distribution by dry sieving through five sieves with $2 \mathrm{~mm}, 1 \mathrm{~mm}, 0.5 \mathrm{~mm}, 0.25 \mathrm{~mm}$, and $0.106 \mathrm{~mm}$ meshes. In this way, structural aggregate units of $>2 \mathrm{~mm}, 1-2 \mathrm{~mm}, 0.5-1 \mathrm{~mm}, 0.25-0.5 \mathrm{~mm}, 0.106-0.25 \mathrm{~mm}$, and $<0.106 \mathrm{~mm}$ in size were separated. Each size class was weighed and its contribution to the total weight of dried soil was calculated.

The water-stable aggregates were measured on the sand-free basis. Size distribution of water-stable aggregates was determined by the wet sieving method [33]: $100 \mathrm{~g}$ of recombined soil, with the same proportion of dry sieving aggregates as the larger sample, was placed in a container filled with deionized water and left to hydrate. After $5 \mathrm{~min}$, the sieve was manually moved up and down 50 times in $2 \mathrm{~min}$. The procedure was repeated, passing the material on to $2 \mathrm{~mm}, 1 \mathrm{~mm}, 0.5 \mathrm{~mm}$, $0.25 \mathrm{~mm}$, and $0.106 \mathrm{~mm}$ sieves, in that order. Soil aggregates retrieved at each sieve were carefully backwashed into beakers and oven-dried at $65^{\circ} \mathrm{C}$ for $48 \mathrm{~h}$. The retained soil was quantified in each sieve, obtaining the above five classes of distinct aggregate diameters. From these mass values and knowing the water content of soil samples submitted to the calculation process, both mean weight diameter (MWD) and geometric mean diameter (GMD) were calculated according to the methods of Six et al. [34] using the following equations:

$$
\begin{gathered}
M W D=\sum_{i=1}^{n} x i w i \\
G M D=\operatorname{Exp}\left[\frac{\sum_{i=1}^{n} w i \ln i}{\sum_{i=1}^{n} w i}\right]
\end{gathered}
$$

where $w i=$ the weight of aggregates $(\mathrm{g})$ within a class of aggregates with an average diameter of $x i$; $x i=$ mean diameter classes $(\mathrm{mm})$.

\subsection{Statistical Analyses}

One-way ANOVA, the significance of the differences among means, and the correlations among soil parameters were all calculated using SPSS 13.0 (SPSS Inc., Chicago, IL, USA) packages. Differences were considered significant with different lowercase letters at $p<0.05$.

\section{Results}

\subsection{Soil Nutrients}

The straw incorporations increased SOC and its related soil nutrients (Table 1). Soils with maize or wheat straw incorporated at $7500 \mathrm{~kg} \cdot \mathrm{hm}^{-2}(\mathrm{M} 3, \mathrm{~W} 3)$ had the highest values of most soil nutrients. The middle (M2, W2) and high (M3, W3) amounts of straw incorporation significantly increased the soil AH-N, $\mathrm{P}_{\mathrm{Olsen}}$, and EK contents over those in CK. The effect of straw incorporation on soil available nutrients was stronger than the effect on soil total nutrients. The accumulation of SOC and its related soil nutrients were higher when the tobacco planting soil was incorporated with maize straw than with the same amount of wheat straw. 
Table 1. Effects of straw incorporation treatments on soil nutrients.

\begin{tabular}{|c|c|c|c|c|c|c|c|c|}
\hline Treatment & $\mathrm{pH}$ & $\begin{array}{c}\mathrm{SOC} \\
\left(\mathrm{g} \cdot \mathrm{kg}^{-1}\right)\end{array}$ & $\begin{array}{c}\text { TN } \\
\left(\mathrm{g} \cdot \mathrm{kg}^{-1}\right)\end{array}$ & $\begin{array}{c}\mathrm{TP} \\
\left(\mathrm{g} \cdot \mathrm{kg}^{-1}\right)\end{array}$ & $\begin{array}{c}\text { TK } \\
\left(\mathrm{g} \cdot \mathrm{kg}^{-1}\right)\end{array}$ & $\begin{array}{c}\mathrm{AH}-\mathrm{N} \\
\left(\mathrm{mg} \cdot \mathrm{kg}^{-1}\right)\end{array}$ & $\begin{array}{c}\text { POlsen } \\
\left(\mathrm{mg} \cdot \mathrm{kg}^{-1}\right)\end{array}$ & $\begin{array}{c}\text { EK } \\
\left(\mathrm{mg} \cdot \mathrm{kg}^{-1}\right)\end{array}$ \\
\hline CK & $6.04^{a}$ & $9.10^{d}$ & $0.70^{c}$ & $0.47^{b c}$ & $18.70^{c}$ & $55.29^{d}$ & $29.85^{\mathrm{cd}}$ & $172.50^{\mathrm{d}}$ \\
\hline M1 & $5.91^{\mathrm{ab}}$ & $9.45^{\mathrm{cd}}$ & $0.72^{b c}$ & $0.46^{c}$ & $19.33 \mathrm{bc}$ & $60.82^{\mathrm{cd}}$ & $26.75^{d}$ & $243.62^{b c}$ \\
\hline M2 & $5.82^{b}$ & $10.05^{\mathrm{abc}}$ & $0.85^{\mathrm{a}}$ & $0.55^{\mathrm{a}}$ & $19.92^{\mathrm{ab}}$ & $69.69^{a b}$ & $31.85^{b c}$ & $270.56^{b}$ \\
\hline M3 & $5.80^{\mathrm{b}}$ & $11.10^{\mathrm{a}}$ & $0.83^{\mathrm{ab}}$ & $0.49 \mathrm{ab}$ & $20.35^{a}$ & $75.83^{a}$ & $61.80^{\mathrm{a}}$ & $314.35^{\mathrm{a}}$ \\
\hline W1 & $5.98^{\mathrm{a}}$ & $9.30^{\mathrm{d}}$ & $0.73^{b c}$ & $0.46^{c}$ & $19.28 \mathrm{bc}$ & $60.09 \mathrm{~cd}$ & $29.65^{\mathrm{cd}}$ & $174.57^{\mathrm{d}}$ \\
\hline W2 & $5.68^{c}$ & $9.78^{b c d}$ & $0.72^{b c}$ & $0.47^{b c}$ & $19.61^{a b}$ & $64.89^{c}$ & $32.45^{b c}$ & $189.73^{\mathrm{cd}}$ \\
\hline W3 & $5.67^{c}$ & $10.62^{a b}$ & $0.86^{a}$ & $0.53^{a b}$ & $19.68^{a b}$ & $66.23^{b c}$ & $36.60^{b}$ & $213.3^{c}$ \\
\hline
\end{tabular}

$\mathrm{CK}=$ no straw control; M1, M2, M3 = maize treatments; $\mathrm{W} 1, \mathrm{~W} 2, \mathrm{~W} 3=$ wheat treatments; $\mathrm{SOC}=$ soil organic carbon; $\mathrm{TN}=$ total $\mathrm{N}, \mathrm{TP}=$ total $\mathrm{P} ; \mathrm{TK}=$ total $\mathrm{K} ; \mathrm{AH}-\mathrm{N}=$ Alkali-hydrolysable $\mathrm{N}, \mathrm{P}_{\text {Olsen }}=0.5 \mathrm{M} \mathrm{NaHCO}_{3}$ extracted P, EK = ammonium acetate extractable K. Different lowercase superscript letters (a, b, c, d) indicate significant differences at $p<0.05$ within a column.

\subsection{Soil Enzyme Activity}

The effects of maize and wheat straw incorporation on soil enzyme activities (sucrase, urease, alkaline phosphatase, and catalase) were shown in Figure 1. Sucrose, urease, and phosphatase activities all increased with the amount of straw incorporated, except phosphatase activity in the wheat straw incorporation treatment; and the highest values were found in the M3 treatment. There was no obvious regularity observed in catalase activity and straw incorporation; the catalase activity in the M2, M3, and W1 treatments was significantly lower than in CK. The minimum value was found in the M2 treatment. These results suggest that both maize and wheat straw incorporation can increase soil enzyme activities, which relate to the SOC, N, and P accumulation and decomposition in the soil.

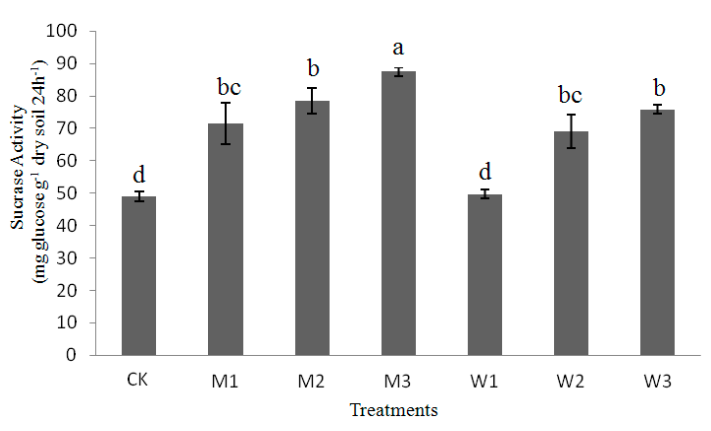

(a)

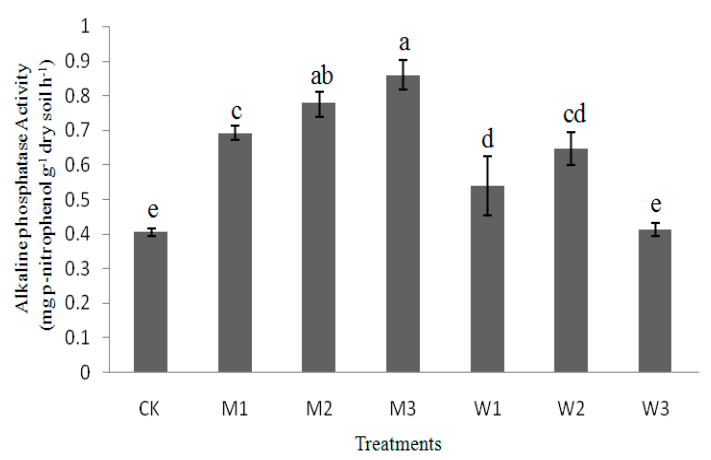

(c)

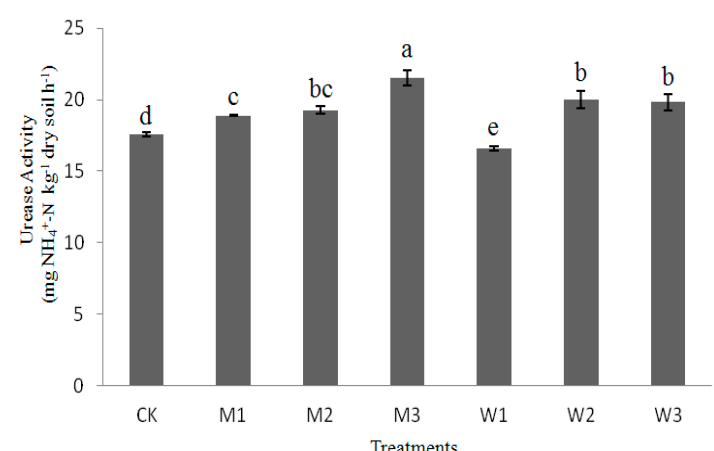

(b)

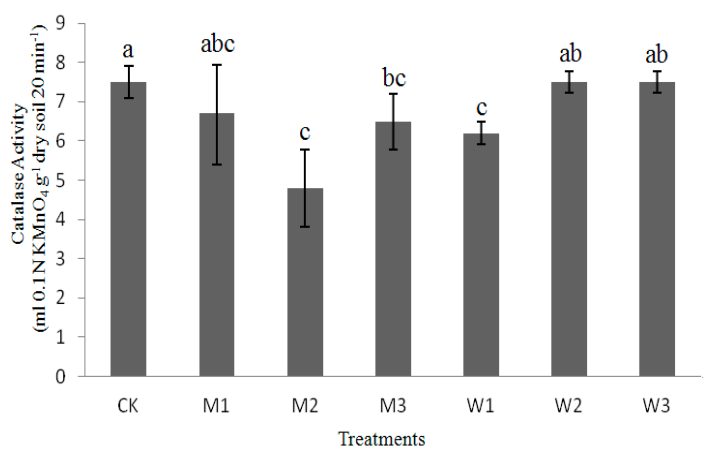

(d)

Figure 1. Effects of straw incorporation on four soil enzyme activities (Error bars within treatments with different lowercase letters were significantly different at $p<0.05$ level). (a) Sucrose activity; (b) Urease activity; (c) Alkaline phosphatase activity; (d) Catalase activity. 


\subsection{Distribution of Soil Aggregate Fractions}

The characteristics of soil aggregates, measured by dry sieving, were shown in Table 2 . The largest aggregate size fraction in all treatments was $>2 \mathrm{~mm}$, which represented $69.55 \%-86.06 \%$ of the total weight. The two next most represented sizes were 1-2 $\mathrm{mm}$ and $0.5-1 \mathrm{~mm}$; these three fractions, together, accounted for $93.90 \%-97.81 \%$ of total weight. The $<0.106 \mathrm{~mm}$ fraction was always the smallest and only accounted for $0.49 \%-1.86 \%$ of the total weight, and the $0.25-0.106 \mathrm{~mm}$ fraction was the next smallest. The percentages of aggregates $>2 \mathrm{~mm}$ were significantly higher in the straw incorporation treatments than in CK, but the percentages of aggregates $1-0.5 \mathrm{~mm}, 0.5-0.25 \mathrm{~mm}$, and $<0.106 \mathrm{~mm}$ had the opposite trend. Furthermore, the maize straw incorporation had a larger $>2 \mathrm{~mm}$ fraction than wheat straw at the same amount.

Table 2. Characteristics of soil aggregates by dry sieving.

\begin{tabular}{|c|c|c|c|c|c|c|}
\hline \multirow{2}{*}{ Treatment } & \multicolumn{6}{|c|}{ Composition of Soil Aggregates (\%) } \\
\hline & $>2 \mathrm{~mm}$ & $2-1 \mathrm{~mm}$ & $1-0.5 \mathrm{~mm}$ & $0.5-0.25 \mathrm{~mm}$ & $0.25-0.106 \mathrm{~mm}$ & $<0.106 \mathrm{~mm}$ \\
\hline $\mathrm{CK}$ & $69.55^{c}$ & $13.37^{\mathrm{a}}$ & $10.98^{\mathrm{a}}$ & $2.88^{\mathrm{a}}$ & $1.37^{\mathrm{ab}}$ & $1.86^{\mathrm{a}}$ \\
\hline M1 & $74.95 \mathrm{bc}$ & $11.32 \mathrm{ab}$ & $8.37^{a b}$ & $2.18^{a b}$ & $1.88^{\mathrm{a}}$ & $1.30 \mathrm{ab}$ \\
\hline M2 & $80.02^{a b}$ & $10.50^{\mathrm{ab}}$ & $6.16^{\mathrm{b}}$ & $1.25^{\mathrm{b}}$ & $1.02^{a b}$ & $1.05^{a b}$ \\
\hline M3 & $86.06^{\mathrm{a}}$ & $7.47^{\mathrm{b}}$ & $4.17^{\mathrm{bc}}$ & $0.95^{b c}$ & $0.86^{a b}$ & $0.49^{c}$ \\
\hline W1 & $76.67^{\mathrm{b}}$ & $11.97^{a b}$ & $7.73^{a b}$ & $1.53^{\mathrm{b}}$ & $1.19^{a b}$ & $0.90^{\mathrm{b}}$ \\
\hline W2 & $77.93^{b}$ & $11.40^{\mathrm{ab}}$ & $6.89 \mathrm{ab}$ & $1.51^{\mathrm{b}}$ & $1.31^{\mathrm{ab}}$ & $0.96^{\mathrm{b}}$ \\
\hline W3 & $83.83^{a b}$ & $10.49^{a b}$ & $3.49^{\mathrm{c}}$ & $0.56^{\mathrm{c}}$ & $0.66^{b}$ & $0.96^{b}$ \\
\hline
\end{tabular}

Different lowercase superscript letters $(a, b, c, d)$ indicate significant differences at $p<0.05$ within a column.

The effects of straw incorporation on the size distribution of water-stable soil aggregates were shown in Table 3. The largest water-stable aggregate distribution fractions in all treatments were $0.25-0.5 \mathrm{~mm}$ and $0.5-1 \mathrm{~mm}$, and the sum of these two fractions accounted for $64.35 \%-51.10 \%$ of total weight. The $0.106-0.25 \mathrm{~mm}$ and $<0.106 \mathrm{~mm}$ fractions were smaller, and the $1-2 \mathrm{~mm}$ fraction was the smallest of all. In general, the percentages of $>2 \mathrm{~mm}, 0.25-0.5 \mathrm{~mm}$ and $0.106-0.25 \mathrm{~mm}$ aggregates were much higher in straw incorporation treatments than in CK. Maize straw incorporation also increased the $>2 \mathrm{~mm}$ fraction more than wheat straw using the same amount. The percentages of $0.25-0.5 \mathrm{~mm}$ aggregates had the opposite trend.

Table 3. Characteristics of soil aggregates by wet sieving.

\begin{tabular}{|c|c|c|c|c|c|c|}
\hline \multirow{2}{*}{ Treatment } & \multicolumn{6}{|c|}{ Composition of Soil Aggregates (\%) } \\
\hline & $>2 \mathrm{~mm}$ & 2-1 mm & $1-0.5 \mathrm{~mm}$ & $0.5-0.25 \mathrm{~mm}$ & $0.25-0.106 \mathrm{~mm}$ & $<0.106 \mathrm{~mm}$ \\
\hline CK & $5.70^{c}$ & $10.27^{\mathrm{a}}$ & $28.34^{\mathrm{a}}$ & $29.90^{c}$ & $11.53^{\mathrm{b}}$ & $14.26^{\mathrm{a}}$ \\
\hline M1 & $13.08^{a b}$ & $4.97^{\mathrm{b}}$ & $16.31^{\mathrm{b}}$ & $34.79^{b}$ & $17.08^{a b}$ & $13.77^{a b}$ \\
\hline M2 & $15.25^{a b}$ & $4.44^{\mathrm{b}}$ & $25.34^{\mathrm{ab}}$ & $32.25 \mathrm{bc}$ & $10.67^{b}$ & $12.05^{a b}$ \\
\hline M3 & $18.82^{\mathrm{a}}$ & $4.41^{\mathrm{b}}$ & $25.47^{a b}$ & $26.13^{c}$ & $13.60^{\mathrm{b}}$ & $11.57 \mathrm{ab}$ \\
\hline W1 & $8.43^{b c}$ & $4.17^{\mathrm{b}}$ & $15.46^{\mathrm{b}}$ & $41.30^{\mathrm{a}}$ & $15.20^{\mathrm{b}}$ & $15.44^{\mathrm{a}}$ \\
\hline W2 & $5.10^{\mathrm{c}}$ & $3.74^{\mathrm{b}}$ & $22.43^{\mathrm{ab}}$ & $41.92^{\mathrm{a}}$ & $11.33^{\mathrm{b}}$ & $15.48^{\mathrm{a}}$ \\
\hline W3 & $10.08^{b}$ & $5.54^{b}$ & $17.03^{b}$ & $39.08^{a b}$ & $19.18^{\mathrm{a}}$ & $9.09^{b}$ \\
\hline
\end{tabular}

Different lowercase superscript letters (a, b, c, d) indicate significant differences at $p<0.05$ within a column.

\subsection{Soil Aggregate Stability}

The effects of straw incorporation on soil aggregate stability were shown in Table 4 . The $M W D_{d}$ and $\mathrm{GMD}_{\mathrm{d}}$ in different straw incorporation treatments were higher than those in CK by dry sieving. There were no significant differences in $\mathrm{MWD}_{\mathrm{w}}, \mathrm{GMD}_{\mathrm{w}}$, or water-stable macro-aggregates $(>0.25 \mathrm{~mm})$ between CK and straw incorporation treatments by wet sieving. Furthermore, the MWD and GMD 
in straw treatments both increased with the amounts of straw incorporation, and treatment M3 $\left(7500 \mathrm{~kg} \cdot \mathrm{hm}^{-2}\right)$ had the highest MWD and GMD by either dry or wet sieving. Straw incorporation increases soil aggregate stability, and the maize straw has a greater effect than wheat.

Table 4. Effects of straw incorporation on soil aggregate stability.

\begin{tabular}{|c|c|c|c|c|c|}
\hline \multirow{2}{*}{ Treatment } & \multicolumn{2}{|c|}{ Dry Sieving } & \multicolumn{3}{|c|}{ Wet Sieving } \\
\hline & $\mathrm{MWD}_{\mathrm{d}}(\mathrm{mm})$ & $\mathrm{GWD}_{\mathrm{d}}(\mathrm{mm})$ & $\operatorname{MWD}_{\mathrm{w}}(\mathrm{mm})$ & $\mathrm{GWD}_{\mathrm{w}}(\mathrm{mm})$ & $>0.25 \mathrm{~mm}(\%)$ \\
\hline CK & $1.69^{\mathrm{c}}$ & $1.51^{\mathrm{c}}$ & $0.63^{b c}$ & $0.44^{\mathrm{ab}}$ & $74.21^{a b}$ \\
\hline M1 & $1.74^{b c}$ & $1.58^{b c}$ & $0.63^{b c}$ & $0.41^{\mathrm{ab}}$ & $69.15^{b}$ \\
\hline M2 & $1.81^{\mathrm{ab}}$ & $1.69^{a b}$ & $0.71^{\mathrm{ab}}$ & $0.49^{a b}$ & $77.28^{a}$ \\
\hline M3 & $1.87^{\mathrm{a}}$ & $1.78^{\mathrm{a}}$ & $0.77^{\mathrm{a}}$ & $0.51^{\mathrm{a}}$ & $74.83^{a b}$ \\
\hline W1 & $1.78^{a b}$ & $1.65^{\mathrm{ab}}$ & $0.55^{b c}$ & $0.37^{b}$ & $69.35^{b}$ \\
\hline W2 & $1.79 \mathrm{ab}$ & $1.66^{\mathrm{ab}}$ & $0.52^{c}$ & $0.38^{b}$ & $73.19^{a b}$ \\
\hline W3 & $1.86^{\mathrm{a}}$ & $1.78^{\mathrm{a}}$ & $0.60^{b c}$ & $0.42^{a b}$ & $71.73^{a b}$ \\
\hline
\end{tabular}

$M W D_{d}=$ mean weight diameter values with dry sieving; $G_{W D}=$ geometric mean weight values with dry sieving; $\mathrm{MWD}_{\mathrm{w}}=$ mean weight diameter values with wet sieving; $\mathrm{GWD}_{\mathrm{w}}=$ geometric mean weight values with wet sieving; $>0.25 \mathrm{~mm}$, the percent of water-stable aggregates which were $>0.25 \mathrm{~mm}$. Different lowercase superscript letters $(\mathrm{a}, \mathrm{b}, \mathrm{c}, \mathrm{d})$ indicate significant differences at $p<0.05$ within a column.

\subsection{Correlations between Soil Enzymes, Aggregate Stability, and Soil Nutrients}

Table 5 shows the correlations between soil enzymes, aggregate stability, and soil nutrients in straw incorporated fields. Sucrase and urease activities were both significantly positively correlated with SOC and AH-N. Alkaline phosphatase was significantly positively correlated with SOC and $\mathrm{P}_{\text {Olsen, }}$ but negatively correlated with $\mathrm{pH}$. There were no significant correlations between catalase activity and soil nutrients except for EK, which had a significantly negative correlation with catalase.

Table 5. Correlations between soil enzymes, aggregate stability, and soil nutrients.

\begin{tabular}{ccccccccc}
\hline Soil variables & $\mathbf{p H}$ & SOC & TN & TP & TK & AH-N & P Olsen & EK \\
\hline Sucrase & -0.50 & $0.91^{* *}$ & 0.15 & 0.17 & -0.64 & $0.95^{* *}$ & 0.39 & 0.54 \\
Urease & -0.55 & $0.93^{* *}$ & 0.00 & -0.08 & -0.60 & $0.91^{* *}$ & 0.12 & 0.38 \\
Phosphatase & $-0.78^{*}$ & $0.89^{* *}$ & 0.33 & 0.16 & -0.45 & 0.60 & $0.80 *$ & 0.72 \\
Catalase & 0.10 & -0.63 & -0.31 & -0.53 & -0.66 & -0.59 & -0.75 & $-0.79 *$ \\
MWD & -0.75 & $0.93^{* *}$ & $0.85^{*}$ & 0.57 & $0.87^{* *}$ & $0.88^{* *}$ & 0.68 & 0.59 \\
GMD $_{\mathrm{d}}$ & -0.75 & $0.92^{* *}$ & $0.85^{*}$ & 0.58 & $0.85^{*}$ & $0.86^{*}$ & 0.68 & 0.56 \\
MWD $_{\mathrm{w}}$ & 0.04 & 0.58 & 0.58 & 0.45 & 0.58 & 0.64 & 0.65 & $0.88^{* *}$ \\
$\mathrm{GMD}_{\mathrm{w}}$ & -0.06 & 0.61 & 0.63 & 0.56 & 0.59 & 0.66 & 0.66 & $0.82^{*}$ \\
$>0.25 \mathrm{~mm}$ & -0.20 & 0.38 & 0.47 & 0.63 & 0.44 & 0.50 & 0.37 & 0.44 \\
\hline \multicolumn{7}{c}{ * significant at $p<0.05 ; *$ significant at $p<0.01}$. & &
\end{tabular}

The $M W D_{d}$ and $G_{M} D_{d}$ had similar trends as the soil nutrients in that they both had significant positive correlations with SOC, TN, TK, and EK. Neither $\mathrm{MWD}_{\mathrm{w}}$ nor $\mathrm{GMD}_{\mathrm{w}}$ had significantly correlations with the soil nutrients except for EK. Furthermore, no significant correlations were found between water-stable macro-aggregates $(>0.25 \mathrm{~mm})$ and any of the soil nutrients. Therefore, the soil aggregate stability measured by MWD and GMD was more vulnerable to dry sieving than that to wet sieving in this study.

\section{Discussion}

The application of crop residue to fields may be the key to promoting physical, chemical, and biological attributes of soil quality in agricultural systems in developing countries [35]. Li and Jin [36] reported that China produced $8.1 \times 10^{8}$ t of crop straw in 2008, and this could be an important organic fertilizer resource. That study showed the application of crop straw had positive effects on soil chemical 
properties. The straw incorporation with the high amount significantly increased SOC, TN, and TK, and the available nutrients in the tillage layer compared with the low amount, or no straw in CK after three years of annual applications in this study. The similar results were also reported by many researchers [6,37-39], where SOC and its related parameter levels increased greatly by the incorporation and decomposition of straw [40]. Furthermore, SOC and its related soil parameters were higher in maize straw incorporation treatment than those in wheat straw treatment with the same amount, which was consistent with other reports [41,42]. It may be related to the higher total $C$ and $N$ content, and relatively lower $\mathrm{C} / \mathrm{N}$ ratio in maize straw than that in wheat straw. Additionally, maize straw might have a relatively higher decomposition rate caused by its lower lignin, cellulose, and hemicellulose concentrations than wheat straw [41]. Therefore, crop straw incorporated to soil could improve SOC content, other soil nutrients and soil carbon storage of farmland, which contribute to the sustainable use of cultivated soil. Meanwhile, the incorporation of crop straw provides a source of readily available $\mathrm{C}$ and $\mathrm{N}$, which would stimulate the greenhouse gas emission [43]. Thus, some necessary measures should be taken, when straw is to be applied, for the sustainability of agricultural field.

Furthermore, our results showed that straw incorporation had a tendency to acidify the tobacco field soil. The incorporation of either straw significantly decreased the soil $\mathrm{pH}$ as compared with that of $\mathrm{CK}$, and the maximum reduction in $\mathrm{pH}$ values was found in the $\mathrm{W} 3$ treatment, which was consistent with previous studies that reported a decrease in soil $\mathrm{pH}$ with the application of wheat straw [44], maize straw [45], or rice straw [46]. The main reason was due to the dissociation of organic acids released from the crop residues [47], or the nitrification of mineralized residue nitrogen [48], which causes a soil $\mathrm{pH}$ decrease by producing protons in the straw residue decomposition. However, there are also some opposite observations regarding the effect of plant residues on soil $\mathrm{pH}$, which may result from differences in composition and type of plant residues, characteristics of soils, and experimental conditions between studies [49].

Soil enzymes are important because of their role in nutrient cycling, and are considered early indicators of specific biochemical reactions in soil, because of their relationship to soil biology, ease of measurement [9,50], and rapid response to soil management changes [51,52]. All soil enzymes, except catalase, had increased after the application of either wheat or maize straw. Soil sucrase and urease both exhibited significant positive correlation with SOC and AH-N. Similarly, the alkaline phosphatase showed significant positive correlation with SOC and $\mathrm{P}_{\mathrm{Olsen}}$, but negative correlation with $\mathrm{pH}$. Catalase activity had no significant correlations with any tested soil nutrients except for EK (Table 5). Increased soil enzyme activities might be due to increased SOC and C and N immobilization during straw decomposition after application, as several studies have shown that soil enzyme activities can be affected by SOC [53-55]. Soil pH did not show significant effects on soil enzymes, except for alkaline phosphatase, in this study. Therefore, SOC was an important factor influencing most soil enzyme activities, and could be an appropriate indicator of soil quality after straw application.

The straw incorporation treatments produced a larger $>2 \mathrm{~mm}$ aggregate fraction than $\mathrm{CK}$, either by dry or wet sieving in this study, which was consistent with the results of Zhang et al. [2], who found that soil physical quality could be improved by adding macro-aggregates through straw incorporation. Meanwhile, the $>2 \mathrm{~mm}$ aggregate fraction and SOC content both increased with the amount of straw incorporated (Table 1, Table 3, and Table 4). This suggests that the straw incorporation promoted formation of macro-aggregates from the loose soil particles, and then accelerated the accumulation of organic matter. This result was similar to Blanco-Canqui and Lal [56] and Li et al. [57], who reported that long-term straw application promoted the formation of soil macro-aggregates and increased SOC concentration and soil aggregate stability. Straw incorporation provides external soil organic matter (SOM) to soil, which serves as the core for aggregate formation [58], causing loose soil particles to stick together and facilitating aggregate formation by combining fungal hyphae, fine roots, root hair, and microorganisms with a high portion of easily degradable polysaccharides $[59,60]$. Soil aggregates can also protect SOM from decomposition by soil microorganisms by forming tight organo-mineral complexes [61]. Meanwhile, higher content of SOM might have a greater effect on 
stability of soil aggregates expressed as MWD and GWD, and they were found to be positively correlated with SOC content in this study (Table 5). When large amounts of organic matter are present, hydrophobic substances formed because straw decomposition can influence aggregation by coating soil aggregates, slowing water invasion, and reducing the rapid wetting effect $[62,63]$. Furthermore, the SOC could improve the soil aggregate stabilization by increasing the soil hydrophobicity and reducing its breakdown [64]. Thus, the result suggested that straw incorporation is an effective practice for improving the soil aggregate structure and stability through the association with SOC.

Nowadays, the loss of SOM is of great concern, particularly as it is commonly low in the arid agricultural soils in Eastern China, where the conventional soil practices involve the removal or burning of crop straws. Therefore, incorporation of maize or wheat straw can promote enzyme activity, soil aggregation, and aggregate stability by increasing SOC content. In addition, the maize straw incorporation at $7500 \mathrm{~kg} \cdot \mathrm{hm}^{-2}$ in this study have a significant effect than others on these soil properties in tobacco fields of Eastern China.

\section{Conclusions}

In summary, SOC, its related parameters, and soil enzyme activities, except for that of catalase, were all increased with increasing amounts of straw incorporated into tobacco field soil. The fraction of $>2 \mathrm{~mm}$ soil aggregates increased more with maize straw incorporation than with wheat straw. The stability of soil aggregates also increased with the amount of maize or wheat straw incorporated. The incorporation of maize or wheat straw might promote soil enzyme activity, soil aggregation, and aggregate stability by increasing the SOC content. Maize straw incorporation had greater effects on these soil physical, chemical, and biological parameters than wheat straw at the same amount. And maize straw incorporation at $7500 \mathrm{~kg} \cdot \mathrm{hm}^{-2}$ is the best choice to improve soil fertility in tobacco fields of Eastern China.

Acknowledgments: This work was financially supported by the National Natural Science Foundation of China (41201291) and the Agricultural Science and Technology Innovation Program (ASTIP-TRIC06).

Author Contributions: Jiguang Zhang conceived the experiments; GuodongBo, ZhongfengZhang and Fanyu Kong conducted and performed the experiment; Yi Wang contributed to reagents/materials/analysis tools. Jiguang Zhang and Guoming Shen designed the experiments, analyzed the data and wrote the paper.

Conflicts of Interest: The authors declare no conflict of interest.

\section{References}

1. Ji, B.Y.; Hu, H.; Zhao, Y.L.; Mu, X.Y.; Liu, K.; Li, C.H. Effects of deep tillage and straw returning on soil microorganism and enzyme activities. Sci. World J. 2014, 2014, 451493. [CrossRef] [PubMed]

2. Zhang, P.; Wei, T.; Jia, Z.K.; Han, Q.F.; Ren, X.L. Soil aggregate and crop yield changes with different rates of straw incorporation in semiarid areas of northwest China. Geoderma 2014, 230-231, 41-49. [CrossRef]

3. Wu, Z.J.; Zhang, H.J.; Xu, G.S.; Zhang, Y.H.; Liu, C.P. Effect of returning corn straw into soil on soil fertility. J. Chin. Appl. Ecol. 2002, 5, 539-542.

4. Pei, S.W.; Zhang, Y.Y.; Liu, J.F.; Mou, Y.J.; Lun, X.X. Greenhouse gas emission under the treatments of fertilization and wheat straw incorporation during the maize growing seasons. Environ. Chem. 2012, 31, 407-414.

5. Christensen, B.T. Straw incorporation and soil organic matter in macro-aggregates and particle size separates. J. Soil. Sci. 1986, 37, 125-135. [CrossRef]

6. Tan, D.S.; Jin, J.Y.; Huang, S.W.; Li, S.T.; He, P. Effect of long-term application of K fertilizer and wheat straw to soil on crop yield and soil K under different planting systems. Agric. Sci. China 2007, 6, 200-207.

7. Zhang, J.; Wen, X.X.; Liao, Y.C.; Liu, Y. Effects of different amount of maize straw incorporation on soil fertility and yield of winter wheat. Acta Metall. Sin. 2010, 16, 612-619.

8. Lehtinen, T.; Schlatter, N.; Baumgarten, A.; Bechini, L.; Krüger, J.; Grignani, C.; Zavattaro, L.; Costamagna, C.; Spiegel, H. Effect of crop residue incorporation on soil organic carbon and greenhouse gas emissions in European agricultural soils. Soil Use Manag. 2014, 30, 524-538. [CrossRef] 
9. Dick, R.P.; Sandor, J.A.; Eash, N.S. Soil enzyme activities after 1500 years of terrace agriculture in the Colca Valley, Peru. Agric. Ecosyst. Environ. 1994, 50, 123-131. [CrossRef]

10. Balota, E.L.; Kanashiro, M.; Filho, A.C.; Andrade, D.S.; Dick, R.P. Soil enzyme activities under long-term tillage and crop rotation systems in subtropical agro-ecosystems. Braz. J. Microbiol. 2004, 35, 300-306. [CrossRef]

11. Pajares, S.; Gallardo, J.F.; Masciandaro, G.; Ceccanti, B.; Etchevers, J.D. Enzyme activity as an indicator of soil quality changes in degraded cultivated Acrisols in the Mexican Trans-volcanic Belt. Land Degrad. Dev. 2011, 22, 373-381. [CrossRef]

12. Nayak, D.R.; Jagadeesh Babu, Y.; Adhya, T.K. Long-term application of compost influences microbial biomass and enzyme activities in a tropical Aeric Endoaquept planted to rice under flooded condition. Soil Biol. Biochem. 2007, 39, 1897-1906. [CrossRef]

13. Fließbach, A.; Oberholzer, H.R.; Gunst, L.; Mäder, P. Soil organic matter and biological soil quality indicators after 21 years of organic and conventional farming. Agric. Ecosyst. Environ. 2007, 118, 273-284. [CrossRef]

14. Garg, S.; Bahl, G.S. Phosphorus availability to maize as influenced by organic manures and fertilizer P associated phosphatase activity in soils. Bioresour. Technol. 2008, 99, 5773-5777. [CrossRef] [PubMed]

15. Verhulst, N.; Govaerts, B.; Verachtert, E.; Mezzalama, M.; Wall, P.C.; Chocobar, A.; Deckers, J.; Sayre, K.D. Conservation Agriculture, Improving Soil Quality for Sustainable Production Systems? In Advances in Soil Science: Food Security and Soil Quality; Lal, R., Stewart, B.A., Eds.; CRC Press: Boca Raton, FL, USA, 2010; pp. 137-208.

16. Amézketa, E. Soil Aggregate Stability: A Review. J. Sustain. Agric. 1999, 14, 83-151. [CrossRef]

17. Lynch, M.; Bragg, E. Microorganisms and soil aggregate stability. Adv. Soil Sci. 1985, 2, 134-170.

18. Roldan, A.; Garcia-Orenes, F.; Lax, A. An incubation experiment to determine factors involving aggregation changes in an arid soil receiving urban refuses. Soil Biol. Biochem. 1994, 26, 1699-1707. [CrossRef]

19. García-Orenes, F.; Guerrero, C.; Roldán, A.; Mataix-Solera, J.; Cerdà, A.; Campoy, M.; Zornoza, R.; Bárcenas, G.; Caravaca, F. Soil microbial biomass and activity under different agricultural management systems in a semiarid Mediterranean agroecosystem. Soil Tillage Res. 2010, 109, 110-115. [CrossRef]

20. Bossuyt, H.; Denef, K.; Six, J.; Frey, S.D.; Merckx, R.; Paustian, K. Influence of microbial populations and residue quality on aggregate stability. Appl. Soil Ecol. 2001, 16, 195-208. [CrossRef]

21. Cui, R.; Li, R.; Han, Q.; Jia, Z.; Liang, L.; Wang, X.; Ma, X. Effects of different organic manure with fertilization on soil aggregates in dry farmland. J. Northwest Agric. For. Univ. 2011, 39, 124-132.

22. Hadas, A.; Rawitz, E.; Etkin, H.; Margolin, M. Short-term variations of soil physical properties as a function of the amount and $\mathrm{C} / \mathrm{N}$ ratio of decomposing cotton residues. I. Soil aggregation and aggregate tensile strength. Soil Tillage Res. 1994, 32, 183-198. [CrossRef]

23. Arshad, M.A.; Coen, G.M. Characterization of soil quality: Physical and chemical criteria. Am. J. Altern. Agric. 1992, 7, 25-32. [CrossRef]

24. Monaco, S.; Hatch, D.J.; Sacco, D.; Bertora, C.; Grignani, C. Changes in chemical and biochemical soil properties induced by 11-yr repeated additions of different organic materials in maize-based forage systems. Soil Biol. Biochem. 2008, 40, 608-615. [CrossRef]

25. Soil Survey Staff. Keys to Soil Taxonomy, 8th ed.; USDA, Natural Resource Conservation Services: Washington, DC, USA, 1998.

26. Lu, R.K. Analytical Method of Soil Agro-Chemistry; Chinese Agriculture Science and Technology Press: Beijing, China, 1999.

27. Sparks, D.L.; Page, A.L.; Helmke, P.A.; Loeppert, R.H.; Soltanpour, P.N.; Tabatabai, M.A.; Johnson, C.T.; Sumner, M.E. Methods of Soil Analysis, Part 3; Chemical Methods ASA-SSSA: Madison, WI, USA, 1996.

28. Li, F.M. Analysis of soil enzyme activity. In Experimental Techniques in Agriculture Microbiology; Li, F.M., Yu, Z.N., He, S.D., Eds.; Chinese Agriculture Press: Beijing, China, 1996.

29. Ge, G.F.; Li, Z.J.; Zhang, J.B.; Wang, J.K.; Xie, X.L.; Liang, Y.C. Geographical and climatic differences in long-term effect of organic and inorganic amendments on soil enzymatic activities and respiration in field experimental stations of China. Ecol. Complex. 2009, 6, 421-431. [CrossRef]

30. Xu, G.H.; Zheng, H.Y. Handbook of Soil Microbiology Analysis Method; Chinese Agriculture Press: Beijing, China, 1986.

31. Six, J.; Elliott, E.T.; Paustian, K.; Doran, J. Aggregation and soil organic matter accumulation in cultivated and native grass land soil. Soil Sci. Soc. Am. J. 1998, 62, 1367-1377. [CrossRef] 
32. Pu, Y.L.; Lin, C.W.; Xie, D.T.; Wei, C.F.; Ni, J.P. Composition and stability of soil aggregates in hedgerow-crop slope land. J. Chin. Appl. Ecol. 2013, 24, 122-128.

33. Barral, M.T.; Arias, M.; Guerif, J. Effects of iron and organic matter on the porosity and structural stability of soil aggregates. Soil Tillage Res. 1998, 46, 261-272. [CrossRef]

34. Six, J.; Elliot, E.T.; Paustian, K. Soil structure and soil organic matter: II. A normalized stability index and the effect of mineralogy. Soil Sci. Soc. Am. J. 2000, 64, 1042-1049. [CrossRef]

35. Turmel, M.S.; Speratti, A.; Baudron, F.; Verhulst, N.; Govaerts, B. Crop residue management and soil health: A systems analysis. Syst. Anal. 2015, 134, 6-16. [CrossRef]

36. Li, S.T.; Jin, J.Y. Characteristics of nutrient input/output and nutrient balance in different regions of China. Sci. Agric. Sin. 2011, 44, 4207-4229.

37. Yadvinder-Singh, B.S.; Ladha, J.K.; Khind, C.S.; Khera, T.S.; Bueno, C.S. Effects of residue decomposition on productivity and soil fertility in rice-wheat rotation. Soil Sci. Soc. Am. J. 2004, 68, 854-864.

38. Chivenge, P.; Murwira, H.; Giller, K.; Mapfumo, P.; Six, J. Long-term impact of reduced tillage and residue management on soil carbon stabilization: Implications for conservation agriculture on contrasting soils. Soil Tillage Res. 2007, 94, 328-337. [CrossRef]

39. Medina, J.; Monreal, C.; Barea, J.M.; Arriagada, C.; Fernando, B.; Cornejo, P. Crop residue stabilization and application to agricultural and degraded soils: A review. Waste Manag. 2015, 42, 41-54. [CrossRef] [PubMed]

40. Wei, T.; Zhang, P.; Wang, K.; Ding, R.X.; Yang, B.P.; Nie, J.F.; Jia, Z.K.; Han, Q.F. Effects of Wheat Straw Incorporation on the Availability of Soil nutrents and enzymy activities in semiarid areas. PLoS ONE 2015, 10, e0120994.

41. Nan, X.X.; Tian, X.H.; Zhang, L.; You, D.H.; Wu, Y.H.; Cao, Y.H. Decomposition characteristics of maize and wheat straw and their effects on soil carbon and nitrogen contents. Plant Nutr. Fertil. Sci. 2010, 16, 626-633.

42. Ogunniyi, J.E.; Guo, C.H.; Tian, X.H.; Li, H.Y.; Zhou, Y.X. The Effects of Three Mineral Nitrogen Sources and Zinc on Maize and Wheat Straw Decomposition and Soil Organic Carbon. J. Integr. Agric. 2014, 13, 2768-2777.

43. Xia, L.L.; Wang, S.W.; Yan, X.Y. Effects of long-term straw incorporation on the net global warming potential and the net economic benefit in a rice-wheat cropping system in China. Agric. Ecosyst. Environ. 2014, 197, 118-127. [CrossRef]

44. Gangaiah, B.; Prasad, R.; Prasad, R. Effect of wheat residue management practices and fertilizers on productivity, nutrient removal and soil fertility of rice-wheat sequence. J. Soils Crop. 1999, 9, 10-13.

45. Lal, R. Long-term tillage and maize monoculture effects on a tropical Alfisol in western Nigeria. II: Soil chemical properties. Soil Tillage Res. 1997, 42, 161-174. [CrossRef]

46. Kushwaha, C.P.; Tripathi, S.K.; Singh, K.P. Variations in soil microbial biomass and N availability due to residue and tillage management in a dryland rice agroecosystem. Soil Tillage Res. 2000, 56, 153-166. [CrossRef]

47. Rukshana, F.; Butterly, C.R.; Baldock, J.A.; Xu, J.M.; Tang, C. Model organic compounds differ in priming effects on alkalinity release in soils through carbon and nitrogen mineralization. Soil Biol. Biochem. 2012, 51, 35-43. [CrossRef]

48. Paul, K.I.; Black, A.S.; Conyers, M.K. Influence of fallow, wheat and subterranean clover on pH within an initially mixed surface soil in the field. Biol. Fertil. Soils 2001, 33, 41-52. [CrossRef]

49. Xu, J.M.; Tang, C.; Chen, Z.L. The role of plant residues in $\mathrm{pH}$ change of acid soils differing in initial $\mathrm{pH}$. Soil Biol. Biochem. 2006, 38, 709-719. [CrossRef]

50. Kizilkaya, R.; Bayrakli, B. Effect of $\mathrm{N}$ enriched sewage sludge on soil enzyme activities. Appl. Soil Ecol. 2005, 30, 192-202. [CrossRef]

51. Kandeler, E.; Palli, S.; Stemmer, M.; Gerzabek, M.H. Tillage changes microbial biomass and enzymes activities in particle size fractions of a Haplic Chernozem. Soil Biol. Biochem. 1999, 31, 1253-1264. [CrossRef]

52. Zhang, Y.L.; Chen, L.J.; Sun, C.X.; Wu, Z.J.; Chen, Z.H.; Dong, G.H. Soil hydrolase activities and kinetic properties as affected by wheat cropping systems of northeastern china. Plant Soil Environ. 2010, 56, 526-532.

53. Cao, C.Y.; Jiang, D.M.; Teng, X.H.; Jiang, Y.; Liang, W.J.; Cui, Z.B. Soil chemical and microbiological properties along a chronosequence of Caragana microphylla Lam.plantations in the Horqin sandy land of Northeast China. Appl. Soil Ecol. 2008, 40, 78-85. [CrossRef]

54. Kujur, M.; Gartia, S.; Patel, A.K. Quantifying the contribution of different soil properties on enzyme activities in dry tropical ecosystems. J. Agric. Biol. Sci. 2012, 7, 763-772. 
55. López, R.; Burgos, P.; Hermoso, J.M.; Hormaza, J.I.; González-Fernández, J.J. Long term changed in soil properties and enzyme activities after almond shell mulching in avocado organic production. Soil Tillage Res. 2014, 143, 155-163. [CrossRef]

56. Blanco-Canqui, H.; Lal, R. Soil structure and organic carbon relationships following 10 years of wheat straw management in no-till. Soil Tillage Res. 2007, 95, 240-254. [CrossRef]

57. Li, H.; Qiu, J.; Wang, L.; Tang, H.; Li, C.; Van Ranst, E. Modelling impacts of alternative farming management practices on greenhouse gas emissions from a winter wheat-maize rotation system in China. Agric. Ecosyst. Environ. 2010, 135, 24-33. [CrossRef]

58. Six, J.; Bossuyt, H.; Degryze, S.; Denef, K. A history of research on the link between (micro) aggregates, soil biota, and soil organic matter dynamics. Agric. Ecosyst. Environ. 2004, 79, 7-13. [CrossRef]

59. Wright, S.; Upadhyaya, A. A survey of soils for aggregate stability and glomalin, a glycoprotein produced by hyphae of arbuscular mycorrhizal fungi. Plant Soil 1998, 198, 97-107. [CrossRef]

60. Bronick, C.J.; Lal, R. Soil structure and management: A review. Geoderma 2005, 124, 3-22. [CrossRef]

61. Edwards, A.; Bremner, J. Microaggregates in soils. J. Soil Sci. 1967, 18, 64-73. [CrossRef]

62. Capriel, P. Hydrophobicity of organic matter in arable soils: Influence of management. Eur. J. Soil Sci. 1997, 48, 457-462. [CrossRef]

63. Blair, N.; Faulkner, R.D.; Till, A.R.; Poulton, P.R. Long-term management impacts on soil C, N and physical fertility physical fertility Part I: Broadbalk experiment. Soil Tillage Res. 2006, 91, 30-38. [CrossRef]

64. Chenu, C. Organic matter influence on clay wettability and soil aggregate stability. Soil Sci. Soc. Am. J. 2000, 64, 1479-1486. [CrossRef]

(C) 2016 by the authors; licensee MDPI, Basel, Switzerland. This article is an open access article distributed under the terms and conditions of the Creative Commons Attribution (CC-BY) license (http://creativecommons.org/licenses/by/4.0/). 